\title{
Wollstonecraft and Godwin: Reading the Secrets of the Political Novel
}

\begin{abstract}
$\mathrm{T}$ he genre of political fiction seems inhabited by certain formative disjunctions. To cast political theory in narrative or dramatic form is to disclose the fictions used in the political world. But on the other hand, the presence of political themes in a literary text assumes an extratextual referent and demands that we confront the problem of how texts are related to the world. The dialectical use of the form as a mixed genre is not inevitable. But the novels of Wollstonecraft and Godwin, in contrast to those of Thomas Holcroft, for instance, cross a particularly 'romantic' threshold in the history of the genre, in that they raise the problem of the textuality of political writing. ${ }^{1}$ We are aware that Holcroft in a novel like Hugh Trevor is constructing a textual world in which characters are invented to fill plot functions, events are related to 'themes,' and captions at the head of each chapter instruct us on how to read. But the purpose of these devices is rhetorical rather than selfreflexive. In constructing an internally coherent paper world, Holcroft simply uses fiction to illustrate ideology and render it persuasive. Wollstonecraft and Godwin, however, use fiction self-consciously to make us aware of reality as a 'text' or system of misrepresentation, but also of ideology as a form of textual desire. As in much romantic literature, the problem of textuality proves inseparable from its ramifications for action and application, but the very notion of application is itself enmeshed in that of representation.
\end{abstract}

${ }^{1}$ My sense of what makes the political novel 'romantic' is different from that of Gary Kelly, who assumes that Jacobin novelists become 'romantic' at the point where they turn from the political to the domestic: The English Jacobin Novel, I $780-1805$ (Oxford: Clarendon Press, 1976). 
Insofar as these texts raise the question of their reading, reading itself emerges as the site of a constant crossing between textuality and referentiality. This chapter accordingly traces the inscription of reading in three texts that compose a critical though not a chronological series. Mary Wollstonecraft's first novel, Mary: A Fiction, is of interest as a point of contrast. Unaware of itself as a text, it neglects the historicity that is part of both writing and reading, and reifies a view of the feminine character that is part of a system of representation. The Wrongs of Woman or Maria, by contrast, raises textuality to thematic prominence. Structured as a series of attempts by people who are literally or metaphorically imprisoned to communicate to those who might be outside, the novel raises the question of reading as a way of cleansing the doors of perception. Through the child, to whom Maria addresses her memoir, it introduces the possibility of a prophetic reader who will complete the text from a later vantage point in the historical process. This model is similar to the one later articulated by Schleiermacher and Hegel, and more specifically by Schelling, who 'divines' the truth behind appearances through negation. But already the teleological historicizing of reading is cast in doubt by our uncertainty as to whether the child exists. In Caleb Williams, finally, the subtext of a divinatory hermeneutics is explicitly explored. For Godwin's novel is not simply a memoir addressed to a future reader by someone who has himself tried to correct past misreadings of the truth. It is also a novel that psychoanalyzes reading so as to implicate readers in the strategies they use. It is the story of how Caleb becomes a spy in order to 'divine' the truth, and it thus creates an infinite regress in which his 'truth' is necessarily suspect, subject to a reading that will make it, too, disclose its hidden secrets.

The previous chapters approach the interaction between text and reader synchronically. But we must also consider the diachronic insertion of the text into future history, if the dialogue between hermeneutics and culture is not to be suspended in aporia. Godwin's own interest in a divinatory hermeneutics emerges in his essay "A Choice in Reading," where he distinguishes between the 'moral' and the 'tendency' of a text. The moral is "an ethical sentence to the illustration of which the work may most aptly be applied," where the tendency is "the actual effect [the text] is calculated to produce upon the reader and cannot be completely ascertained but by experiment." 2 Or put differently, the moral is the

\footnotetext{
${ }^{2}$ Godwin, "A Choice in Reading," The Enquirer: Reflections on Education, Manners, and Literature, 2 vols. (Philadelphia: 1797), I, 109. I am indebted to David McCracken's essay "Godwin's Literary Theory: The Alliance between Fiction and Political Philosophy," Philological Quarterly 49 (1970): 113-33. McCracken does not place Godwin's aesthetic theory in relation to the hermeneutic tradition. But his article provides a thoughtful analysis of some of the tensions in Godwin's essay.
} 
authorial intention, whether original or final, whether established before the process of writing or in retrospect through a series of rationalizations and subterfuges. ${ }^{3}$ The tendency, on the other hand, is an intersubjective and historically developing significance, generated by the interaction of intention and its representation and subsequently of the text and its reading. Thus authors "show themselves superlatively ignorant of the tendency of their own writings," which "has of ten lain concealed for ages" from their "most diligent readers." 4 Unlike Wordsworth, who similarly relates the text to its future in his "Essay, Supplementary to the Preface," Godwin frees the reader from an auxiliary role and makes history the site of difference rather than of an atemporal vindication of authorial identity. It is clear that for Godwin, who criticized Holcroft for his didacticism, meaning is shifted by its articulation in language, ${ }^{5}$ and that is why the reader cannot be governed by the announced moral, but must read actively, doing more than simply reproducing the text. For by making writing the production rather than the reflection of an anterior meaning, Godwin also makes reading the production, through 'experiment' or experience, of a text that is still in process. At the same time, he is reluctant to give way to a complete relativism. Hence, his historicizing of intention takes the form of a divinatory hermeneutics, which imposes a teleological direction on the history of reception, consistent with his own notions of perfectibility. He uses the metaphor of recovery and speaks of a truth that has "lain concealed." He assumes a prophetic reader who will uncover the "genuine tendency" of the text, ${ }^{6}$ and whose principles will coincide with those of Godwin himself. For instance, Nicholas Rowe's The Fair Penitent may have been written as a critique of illicit love, but despite itself, what it does is to expose the limitations of certain attitudes toward women. Like Shelley's reading of Milton, Godwin's reading of Rowe goes beyond the moral discerned in a merely grammatical reading, to a deeper tendency that becomes evident only through the enlightened reading that historical progress makes possible; and like Shelley, Godwin seems to regard this second reading as definitive.

But clearly this theory of reading calls into question the very model that it introduces. For in shifting from a mimetic to a hermeneutic view of the text, Godwin, like Hegel and Schelling, also historicizes the pro-

${ }^{3}$ Godwin, "A Choice in Reading," p. 107.

${ }^{4}$ Ibid., p. 106.

${ }^{5}$ For instance, Godwin argues, "If the moral be invented first, the author did not then know where the brilliant lights of his story would fall, nor of consequence where its principal power of attraction would be found. If it be extracted afterwards he is of ten taken at a disadvantage, and must extricate himself as he can" (ibid., p. 107).

${ }^{6}$ Ibid., p. 106. 
cess of interpretation. He thus allows for the divinatory model itself to be read as a peculiarly 'romantic' construction: romantic in the way it reimposes the desire for unitary meaning on a deference to the reader that disestablishes both author and authoritative meaning. If Godwin's intention is to propound a divinatory hermeneutics, the tendency of his essay is to promote an 'historical' reading whose status is heuristic rather than traditionally hermeneutic, because it recognizes that the truth one divines is always the representation of a particular ideological will. For one thing, the concept of the text as tendency is much more open than a divinatory hermeneutics can allow: the word 'tendency' does not suggest anything determinate enough to ground meaning. Just as in Godwin's view the writer who tries to impose a final intention on his text scrambles belatedly to simplify what has become complex, so, too, readers who attribute such an intention to the world-historical process exert their own will-to-power in reducing a tendency to a direction. This chapter therefore discusses how the political novel, instead of simply transferring traditionally hermeneutic models into the text, produces the heuristic tendencies of Godwin's aesthetic theory. In doing so, it draws on Kierkegaard's displacement of traditional hermeneutics but also on descriptions of textual structure borrowed from contemporary Marxism. This is not because the analysis offered here is specifically Marxist. Rather, it is because Marxist reading itself develops from the hermeneutic tradition, specifically from Hegel's Aesthetics, which re-visions dissonances between the "idea" and its "embodiment" from a later vantage point. Inasmuch as earlier Marxist theory shared the tendency of a traditional hermeneutics to explain the text from a later vantage point and to desire (if not to achieve) its closure, more recent Marxist criticism can be used in reverse to refigure its parent tradition and decouple it from the nostalgia for closure.

Reading beyond the Ending: From Maria to The Wrongs of Woman

Wollstonecraft's prerevolutionary first novel provides a good starting point, not so much because it thematizes its status as fiction as because it fails to do so. For Mary: A Fiction presents itself as an imitation of reality, without much awareness that this reality is itself written by literary and social conventions, and therefore without much awareness of a reader who might read its story otherwise. Rachel Blau DuPlessis has pointed to the predominance in novels about women of plots ending in the marriage of the woman and her assimilation into the male system of values, or in her death and in the implied failure of her search for an autono- 
mous identity. ${ }^{7}$ It is the second version of this cultural script that is played out in Mary, where at the end the heroine waits to die. Given that the very conventions of narrative seem ideologically infiltrated, the problem for the woman writer becomes one of using narrative structures against themselves so as to stimulate the reader to think beyond them. "Writing beyond the ending," as DuPlessis defines it, involves "the transgressive invention of narrative strategies, strategies that express critical dissent from dominant narrative." 8 Such strategies invite us to go beyond a purely grammatical reading of what is said in the text, to an articulation of what Macherey calls its absences and silences. Far from being uniquely feminist, reading beyond the ending is essential to any political reading - whether divinatory and utopian as in Hegel or more cautiously historical as in Macherey-and political reading is itself a development of the hermeneutic tradition. But it is precisely such reading that Mary, on a formal level, resists.

The closed form of Mary is consistent with Wollstonecraft's other writings of this period. The Female Reader, a series of moral and religious readings for young women, differs markedly from $A$ Vindication of the Rights of Woman in assigning women to the domestic sphere and in refusing to see social psychology as something historically produced. Its instructional form assumes the anterior presence of universal truths, without raising the question of their representation. Didactic prose does not usually call into question its status as truth. But the Cave of Fancy, a fragmentary philosophic tale begun in 1787 , is similar in its epistemology. The title suggests a neoplatonic framework that associates truth not with history but with a higher realm. The sage Sagestus watches over a purgatorial cave where potentially virtuous spirits come to be reeducated. The text was to consist of a series of autobiographies told by the spirits in order to educate a child the sage had rescued from a shipwreck. The only one of these to appear in Posthumous Works concerns a woman who marries for duty, sublimates her love for another man, and eventually concludes that it would have been neglect of God to indulge this love.$^{9}$ Stories are passed on from generation to generation here, but the model of transmission remains one of passive absorption. In keeping with this view of truth as fixed are the parabolic form and exotic oriental setting of the tale, which posit a truth that is esoteric rather than imme-

${ }^{7}$ Rachel Blau DuPlessis, Writing beyond the Ending: Narrative Strategies of Twentieth-Century Women Writers (Bloomington: Indiana University Press, 1985), pp. 1-4.

${ }^{8}$ Ibid., pp. 5, 7 .

9Wollstonecraft, "The Cave of Fancy," in William Godwin, ed., Posthumous Works of the Author of a Vindication of the Rights of Woman, 4 vols. in 2 (Clifton, N.J.: Augustus M. Kelley, 1972), II, 154 . 
diately accessible, but that is also universal and (by virtue of its setting) culturally despatialized.

Where these other texts involve the reader rhetorically if not heuristically, Mary seals itself against even our passive participation. The story is a conventional one, as if written ventriloquistically by the various cultural voices for which 'Wollstonecraft' is a gathering point. Yet it is offered to us as an "artless tale" in which "the soul of the author is exhibited" ( $M W W$, p. xxxi) and in which there is therefore no need to read beyond what is said. At the beginning Mary seems significantly different from her mother Eliza, a "mere machine" $(M W W$, p. 1). But her 'identity' proves largely vicarious and consists of attempts to define herself through philanthropy, through her unsatisfying friendship with Ann, and through her love for the dying Henry, a person even more sickly than herself. Throughout the novel we are aware of an inner void that cannot be filled by others, of an excessive sensibility that verges on narcissism. Her one attempt at an independent identity, her decision to work, is quickly forgotten. By the end of the novel, Wollstonecraft's attempt at representing a new woman and the protagonist's attempt at self-representation have both collapsed. Resignedly, Mary adopts a voice of religious deferral, as she anticipates "hastening to that world where there is neither marrying, nor giving in marriage" ( $M W W$, p. 68). The oddly critical and irritated attitude toward Mary, who is initially supposed to provide a model of the new intellectual woman $(M W W$, p. xxxi), seems written by the reaction against the cult of sensibility in which Wollstonecraft's middle-class pragmatism forces her to share. Yet at the same time, and despite the fact that Mary is derivative and formed by a "fondness for reading tales of woe" that her sensibility causes her to live out $(M W W$, p. 6$)$, her author is also attracted to the tradition of sensibility, because it offers her the only available discourse that values feminine qualities. This double deformation of the novel's emotional identity, in which neither the protagonist's style of awareness nor the voice that criticizes it rings true, creates a gap in the text that stimulates us to read beyond the languages in which it is constrained to speak. But it is precisely such reading that the novel, through its closed and unreflexive form, discourages. Its terse style, consisting of short chapters in which plot dominates character, creates a sense of inevitability and allows the reader no space in which to think beyond the design imposed on her by the plot. Monologically unified, the novel lacks the exploratory distractions and alternative turnings provided by subplots and stories within stories. As important, it does not thematize the problem of reading through characterized readers or scenes of reading that mark the possibility of reading otherwise. Maria in The Wrongs of Woman makes desperate attempts to communicate to others who inhabit 'realities' dif- 
ferent from hers. But the only thematized form of communication in Mary is the heroine's diary $\left(M W W\right.$, p. $\left.5^{1}\right)$, a narcissistic medium that offers her no exit from the forms in which she is conditioned to represent herself.

Mary, in short, institutionalizes a representation of women as doomed to fail because of their sentimental nature. Yet this "nature" is itself developed within a social text that assigns women the genre of sensibility. Although the actual reader may read beyond the novel's end, however, the text itself does not write beyond its ending by explicitly thematizing the historicity of its representations. With $A$ Vindication of the Rights of Woman Wollstonecraft begins to view the condition of women historically. She provides a polemical rereading of Mary and ironically echoes its last sentence, ${ }^{10}$ resituating her first novel and arguing that excessive sensibility is an effect of society's denying women an independent professional and financial identity. This rereading continues in The Wrongs of Woman, which rewrites Mary so as to turn it in a more revolutionary direction. The protagonist's name, Maria, is similar and there is a parallel love triangle: Maria has been married to Venables but falls in love with Darnford; Mary, too, had been married to a husband she did not love and had formed a Platonic attachment with the dying Henry. The differences in plotting are, however, much more striking. Mary's husband, Charles, is inoffensive and allows her to stay away from him for long periods, during which she meets and then tends Henry. George Venables, by contrast, forces Maria to give him her property, tries to make her into a prostitute for the gratification of his business associate, and finally imprisons her in a private asylum. Moreover, the problem of sensibility is now specified as socially caused: "In a life of such seclusion," the narrator comments, "the passions gain undue force" $(M W W$, p. 91). Not only does Maria's incarceration in a literal prison externalize a psychological or biological condition as a social one. Its manif est injustice also provokes the reader to revolt against the prison of things as they are. Other changes likewise contribute to this rewriting of a fatalistic novella as a radical novel. Henry Darnford is less sickly than Henry and initially represents Wollstonecraft's hope that a change in male attitudes is not always already doomed. Maria is given a child and made to seem more mature, oriented toward the future rather than the transcendent, and capable of the fruitful relation to life she is denied. Anne, the consumptive friend whom Mary helps and accompanies to Portugal, is replaced by Jemima, who introduces into the novel the particular problems faced by lower-class women.

As important is the greater structural complexity of the novel, which

${ }^{10} \mathrm{~A}$ Vindication of the Rights of Woman (New York: Norton, 1967), p. 68. 
does not consist of a plot that imitates an action, but of Maria, Jemima, and Darnford telling each other their life stories. The result is to foreground the issue of (self) representation: to shift attention from what happens to how people narrate what happens. Maria's story, for instance, is cast in terms of the sentimental novels she is fond of reading. As she tells her tale of male oppression and expresses sentiments of feminist radicalism, she continues to look to men like her uncle and Darnford for help: she plays out her life in terms of romance conventions such as the ideal lover who will prove to be a knight in shining armor. Jemima's story is similarly formulaic, but according to the conventions of the jaded and fatalistic working-class realism we also find in some of Blake's Songs. Significantly, these stories are full of hiatuses and subject to awkward interruptions, like the "indistinct noise" that abruptly terminates Jemima's story $(M W W$, p. 118). As Mary Poovey observes, Wollstonecraft breaks off the characters' stories because she senses that the reader is being drawn "into stories that are patently not true and whose aesthetic closure would artificially resolve whatever politically effective emotions the stories might arouse." 11 What the emphasis on stories brings out is the way narrative and life mutually articulate each other, the power of narrative over life, and the need to read beyond the way we write ourselves.

It is no accident that these stories are all replayed in the setting of a prison. Through Maria's sentimental rhapsodies and her autobiographical memoir, writing is repeatedly thematized not only as a substitute for action $(M W W$, p. 82) but also as a confining repetition of the past. But if the narcissistic sensibility of the memoir recalls Mary's diary, it also differs from the latter in being addressed outside the self, in being an intent at communication as well as self-expression. Moreover, reading and communication are associated with an attempt to transcend one's own condition. Crucial to the implication of the reader in the text is the exchanging of stories among the three main characters, which marks their attempt to move beyond the imprisoning roles they write themselves into and also functions as a hermeneutic signal that invites us to read beyond and between the lines of their stories. Through Maria the text, as we shall see, sometimes thematizes the wrong kind of reading. But Jemima, her jailer who in her own way is equally oppressed, reads to educate herself $(M W W$, pp. 112-13). It is through reading that Maria and Darnford begin to know each other: she by reading the marginalia he has written in books he loans her, and he by reading her memoir,

${ }^{11}$ Mary Poovey, The Proper Lady and the Woman Writer: Ideology as Style in the Works of Mary Wollstonecraft, Mary Shelley, and Jane Austen (Chicago: University of Chicago Press, 1984), pp. 106-7. 
which is to be passed on to Jemima. However limited the success of these characters may be in reading each other, their exchanging of textual and narrative materials sets up a circuit of communication which can be projected beyond the text itself and in which Wollstonecraft's novel then takes its place. By placing itself in this circuit, the novel suggests that writing is not the reproduction of a fixed meaning assumed in Mary; rather, it is an occasion for reading, and for a meaning yet to be produced.

This is not to suggest that reading is represented unproblematically. Indeed, the novel questions the fiction of a transparent reading put forward when Darnford seeks to know Maria by reading her memoir, or when we imagine that we know Mary Wollstonecraft because her editor has "give(n) to the public the words, as well as the ideas, of the real author." 12 When Maria reads, she reads Dryden, Milton, and Rousseau, at least two of them authors whom Wollstonecraft repudiates in A Vindication. Maria's reading of Heloise is particularly pernicious because it encourages her to become the sentimental heroine in search of an "ideal lover" $(M W W$, p. 89$)$, and thus to play out the melodramatic version of Rousseau's romance script by becoming the betrayed mistress of the concluding fragments of the novel. How then can we hope to grasp the true Maria by reading her memoir, when the way she represents herself is itself shaped by her reading? The dangers of a merely passive reading are intimated by Wollstonecraft herself when she describes how Maria looks for "tale(s) of fictitious woe" that bear a "resemblance to her own" $(M W W$, p. 81$)$ and then allows herself to be coopted back into what she is trying to escape.

But almost unobtrusively, the novel suggests a second model of reading. For Maria also reads the marginalia written by Darnford in the books he lends her. Though she herself does not reflect on the ramifications of what she is doing, what she brings out is that the activity of reading occurs in the margins and between the lines of the text. Given that writing, even when it is constituted as criticism, is still a reproduction of ideology that can do no more than display its gaps, reading must do more than also simply reproduce what is said or intimated. It must articulate what is not said or what is said only through those "determinate absences which twist [the text's] various significations into conflict and contradiction," to quote Eagleton. ${ }^{13}$ The answer that the text seems to provide to our question of how we are to grasp the true Maria is that we cannot simply read her memoir or even the novel in which it is contained. The true self is still liminal, written in the margins of other

${ }^{12 G o d w i n ' s ~ p r e f a c e ~ t o ~ P o s t h u m o u s ~ W o r k s, ~ I, ~ n . p . ~}$

${ }^{13}$ Terry Eagleton, Criticism and Ideology: A Study in Marxist Literary Theory (London: Verso Editions, 1978), p. 89 . 
people's texts. The kind of reading that the novel elicits, then, is neither a surface reading that confirms it as a tale of woe, nor a deeper but still positive reading that acts upon the desire intimated in it: the desire for a sentimental ending in which Maria is united with Darnford. Rather, we are invited to practice a negative reading that unfolds a meaning shadowed in the text but not yet contained in it as either manifest or latent content.

Crucial to the negativity of the text is the way it fragments narrative to prevent us from settling into any single story of how things are. Each of the characters' stories negates itself as a historically limited misrepresentation. The result is that the meaning of the text does not seem to inhere anywhere in it but remains to be produced. ${ }^{14}$ In keeping with the relationship it establishes between reading and negativity, the novel is careful not to identify the true practice of reading with any of its own characters. As a reformed version of Venables, Darnford projects the potential for change within a male audience and seems Maria's desired reader. But although Darnford and Maria meet obliquely by exchanging marginalia and memoirs, the distance of reading is never quite overcome. Their conversations are repeatedly interrupted, as if to inhibit us from settling into a fiction of transparent communication. Moreover, Darnford comes across as a shifting plot function rather than as a personality. His character is not fully worked out: the events of his life history are flat and clichéd, as if inserted to fill a space, while his role in Maria's life is left vague. It is never clear whether they have met before their imprisonment $(M W W$, p. 93), nor is it clear how he behaves after they leave the asylum. This refusal to specify Darnford's character raises but defers the possibility of a hermeneutic reading. It holds before us the possibility of true understanding, but without anchoring it in any particular person or social group. The figure of an appropriate reader is similarly constructed and deconstructed through the child. Never actually materializing in the plot, announced as dead toward the middle of the novel, and then ambiguously brought back in one of the endings, the child functions as a floating hermeneutic signifier. Like the child in Coleridge's "Frost at Midnight," it allows the text to point beyond the present and to represent a change that may actually have to occur through rupture in the reassuringly predictive terms of genesis and filiation. But because the child, unlike Hartley Coleridge, is entirely outside the text, the un-

\footnotetext{
${ }^{14}$ Poovey's otherwise excellent discussion treats Jemima's story as having more authority than Maria's and as leading us toward the repressed content of the novel. Her reading typifies the tendency of a Marxist historicism to see the text as limited by the historical circumstances of its production. My own reading, by contrast, does not allow us to settle into a Marxist dismissal of the novel by arguing that it contains a true meaning that it represses and the critic uncovers.
} 
derstanding it promises and the application of that understanding to life cannot be identified with anything achieved in the novel. The possibility of reading beyond the present remains disembodied, deferred to a reader who exists only as a shadow.

The (de)construction of the reader allows for no definite terminus to the negativity of the text. But we must distinguish between the way the text actually functions and the reading 'Wollstonecraft' inscribes in it. Logically, the process of negative reading cannot reach a positive conclusion. The text, as Eagleton points out, is "never at one with itself. . . . It is, rather, . . . an attempt to overcome the problem of itself, a problem produced by the fact that the text itself is the production rather than the reflection of an ideal 'solution."' 15 Because reading is similarly a production of ideology, it, too, is never at one with itself. Up to a point 'Wollstonecraft' uses this negativity as the propulsive force behind her text, and uses it even at the end to disengage us from a reading too identified with the figure of Maria. But in the chancery scene she also imposes a premature closure by positing a correct reading: an ideological key to the text, furnished in $A$ Vindication and activated in this novel through a hermeneutics of reversal. In this respect she follows the pattern typical of a negative hermeneutics such as that of Schelling, who explores what is unsaid only to turn around and build a positive statement on it through a dialectical reversal of the unsaid into the said. We have seen in the case of Kierkegaard how this romantic impulse toward closure is reopened, how he explores the subtext of negative hermeneutics through a form of negative reading paralleled by developments in contemporary Marxist and psychoanalytic theory. In displacing negative hermeneutics into negative reading, Kierkegaard reads beyond Schelling's residual impulse toward Hegelian closure: he takes the latter's attempt to end the negation of external surfaces by deciphering the metaphysical unconscious and reads the unconscious (which Kierkegaard calls the Governance) as itself a text. It seems similarly true to the novel's political unconscious to reopen the strategies of reading that Wollstonecraft herself inscribes in The Wrongs of Woman.

But first we must describe the way 'Wollstonecraft' tries to make the reader wrest a positive meaning from the climax of what was intended to be part II. For there is little in the way the story unfolds to suggest that The Wrongs of Woman is any less fatalistic than Mary. The first part ends with the memoir as it breaks off on a note of despair, with Maria now in the asylum. In the second part, sketchily outlined in the last three chapters, Maria escapes and lives for a while with Darnford, though not in "uninterrupted felicity" ( $M W W$, p. 192), and then fails to obtain a di- 
vorce. The fragments printed by Godwin in the conclusion sketch various versions of the third part, and with one exception the saga continues from bad to worse: among the woes still in store for Maria are an award of damages to her husband, pregnancy, miscarriage, and suicide. The structure of the novel, however, is such that its meaning is contained not in the narrative itself but in the interaction between the text and its future reader. By the end of the chancery suit several features have combined to elicit a reading based on a hermeneutics of reversal. To begin with, there is the pairing of the novel's title with that of Wollstonecraft's political treatise, which suggests that 'enveloped' within the wrongs of woman are the rights of woman, which can be unfolded through the model of counterreading articulated by Schelling. The resolution of the chancery suit, moreover, is highly melodramatic, with the judge tyrannically refusing Maria's request for a divorce and the right to her own property, even as he concedes that the decision might be different in a different court $(M W W$, p. 199). This naked assertion of prejudice is inflammatory, and the text thus provides an antithetical stimulus to the reader to transfer the venue of the action to the court of public opinion. Melodrama is, after all, a demonic form of romance, and its plots call for imaginative reconversion into what they should be. Peter Brooks has pointed out how nineteenth-century melodramas of ten include the character of a mute. ${ }^{16}$ Silenced by society and forced into a nightmarish reality, the mute is a radicalizing figure with a specific rhetorical function. In the courtroom Maria has been muted and feels compelled to present her case in a paper that is read out. Our desire as readers is to give her a voice once again, to restore to her the power to act as well as to write through her words.

But the text does not simply call for an inversion of its plot, in which Maria is granted a divorce and lives happily ever after with Darnford. Maria has been silenced at a more significant level than simply not speaking in court, and the problem of the novel is not solved simply by reinvesting her text with the power of speech and action. We have already commented on the melodramatic, almost gothic, quality of the novel with its tale of imprisonment in an "abode of horror" and its brutal male villain, more sociologically specific but as nightmarish as Radcliffe's Montoni. The interest of women writers in the gothic, as several critics have suggested, derives from its ability to suggest an experience of frustration and confinement, a world that is internally disordered and split with no possibility of transcendence. ${ }^{17}$ The Wrongs of Woman is a form of

16The Melodramatic Imagination: Balzac, Henry James, Melodrama, and the Mode of Excess (New Haven, Conn.: Yale University Press, 1976), pp. 56-75.

${ }^{17}$ For various points of view on the subject see Juliann E. Fleenor, ed., Female Gothic (Montreal: Eden Press, 1983). 
political gothic which retains the gothic setting as a socially imposed metaphor so as to exhibit critically the emotional excesses of the form and its complicity in the attitudes of patriarchy. For another feature of the gothic is that it is nightmarishly unreal. It twists reality so as to make us question whether what we are reading is really happening. Because the gothic deformatively produces archetypes as stereotypes, it bears out Nancy Miller's claim that "the plots of women's literature are not about 'life' and solutions. ... They are about the plots of literature itself." 18 The fraudulent and fabricated quality of the gothic romance has, in this novel, the effect of a double negation. It is as if the actual ending of Maria's story, in which villainy triumphs, is projected onto a screen, theatricalized, and replayed as a cultural nightmare. But at the same time the happy ending for which Maria pleads is similarly made to seem like a cinematic dream. Maria's political radicalism is only a thinly veiled disguise for her sentimentalism, union with her lover being simply the dream equivalent for the nightmare of imprisonment by the villain. The fact that the chancery scene is not yet about solutions but about plot, about the power that imposes narratives or the desire that produces them, compels us to read beyond Maria's defense as well as the legal decision. In its polemical tone Maria's defense resembles $A$ Vindication, but the differences are fundamental. Her plea for divorce is simply a plea to reenter the matrimonial system over again, whereas Wollstonecraft is concerned with establishing psychological and therefore economic autonomy for women. Maria's defense is still represented as a text, and we must read its margins to bring out what she has not found a social language to articulate. However, as the pairing of the titles indicates, reading the social text as a negative transparency is not in Wollstonecraft's view an endless process. In order to unfold the rights that are 'enveloped' within the wrongs of woman, one turns to $A$ Vindication, which specifically treats what is occluded from Maria's manifesto: the problems of sensibility, of female autonomy, and of the need for feminism to include a critique of society that will study the intersection between gender and class. The reader is encouraged to turn to A Vindication because Maria's text, though still a form of writing and therefore of repetition, is emergently different from her memoir and effusions. It at least adopts the language, if not yet the content, of a political critique grounded in a materialist analysis.

Were the novel to end with the trial scene, ${ }^{19}$ reading it would not be

\footnotetext{
${ }^{18}$ Nancy Miller, "Emphasis Added: Plots and Plausibilities in Women's Fiction," PMLA $96(1981)$, p. 46.

${ }^{19}$ I assume here that the author's text concludes with the chancery scene and that the fragments are part of the editor's text. But the question of where we draw the boundary between the text and its editing is a difficult one, as is the question of Wollstonecraft's
} 
endlessly complex. But the various projected endings appended by Godwin force us to map the territory between present and future, between the judge's response and the just society we are provoked into constructing in our minds. Two detached sentences, based on Wollstonecraft's own experience with Imlay, raise the possibility that Darnford may prove disloyal. If so, then the hope that there exist some progressive men falls apart, and it is this hope that helps us to believe that the rights of women can be vindicated, even though power is exclusively vested in the hands of men. Of the "scattered heads for the continuation of the story," most mention Darnford's treachery and consist of brief pointform formulae whose predictability makes us question whether Maria will not automatically fall back into a male script. These endings reinscribe The Wrongs of Woman in the feminine fatalism of Mary and make it once again into a tale of woe. But the most fully worked out of the paragraphs is different. It shows Maria having tried to kill herself by taking laudanum and deciding to live for her child, whom Jemima has found. This scenario, in which Darnford does not appear, and in which the daughter is a figure for a resurrection of hope based on an exclusively feminist society, interested Wollstonecraft enough for her to develop it at greater length than the others. Where the chancery scene has a revolutionary effect, the various endings are self-canceling, though not necessarily in a hopeless way. None of the endings involving Darnford is elaborated in sufficient detail to acquire any mimetic authority, and all of them are too based on clichés to ring entirely true. Their fragmentation and mechanization is a way for the text to write beyond itself, to exhibit the conventionality of the systems of representation it is forced to use, even as it stops short of overturning them or replacing them. Paradoxically, the manner in which these endings base

\footnotetext{
'intention.' On the one hand, there is 'Wollstonecraft's' text, which ends with the chancery scene. This text is more of an aesthetic whole than the one we have, on a hermeneutic if not on a formal level. Ending with a provocative crisis, it seems to have been cut of $f$ by the author's death, and the pathos of this 'fact' leads us to vindicate Maria and complete her moral-political education. But this text, if it existed for us, would be Godwin's text as much as Wollstonecraft's, because it would exist only through Godwin's decision to suppress a part of what his wife had actually written. We can speak of this text as the one Wollstonecraft intended because it seems to be in accord with $A$ Vindication, and on some level she probably did intend it. But the Wollstonecraft who intended it is also a 'figure,' a figure perhaps constructed by Wollstonecraft herself in a radical mood. On the other hand, we have spoken as if the text that results from the printing of the various fragmentary endings is Godwin's, and indeed it is unlikely to have been the text with which Wollstonecraft, had she lived, would have presented us. But who is to say that it does not represent her intentions on some other level, on that level explored by Schleiermacher when he discusses a psychological reading that does not yield a unified meaning because it includes subtextual and collateral thoughts? The circumstances of the text's publication necessarily blur the boundary between Wollstonecraft and Godwin, between text and apparatus, author and editor.
} 
themselves on Wollstonecraft's own life also limits their authority, by making too personal the repetitive and compulsive replaying of the author's anxieties. As importantly, Wollstonecraft does not incorporate them into the novel and does not thereby prevent us from reading the story otherwise. They are transmitted to us by Godwin as possibilities we must play with, probabilities we must think beyond, cultural anxieties that may continue to haunt our attempt to move beyond them. On the other hand, if the perfunctoriness of these endings reduces their authority, the greater length of the hopeful ending does not make it more realistic. Maria's final cry, "The conflict is over!-I will live for my child!" ( $M W W$, p. 203), is conventional in its own way, its melodrama the sign of some voice that still remains muted and requires further reading. In practical terms we may wonder how feasible an isolationist society built around Maria, Jemima, and the child will prove to be, and that doubt is registered in Wollstonecraft's suggestion that the child itself may be a mirage: "A new vision swam before her. Jemima seemed to enter-..." (MWW, p. 203). Moreover, it is clear that the resolution projected here is still reactively shaped by the psychorhetorical systems it resists. If Maria's decision to live is an assertion of female autonomy, there is in her decision to live for her child and not herself a trace of the desire to bury herself that was evident in her attempt at suicide.

The editorial presence of Godwin adds yet another layer to the novel, distancing us from the author's voice and presenting both Wollstonecraft and her fiction to us as a text. For Godwin's introduction, interpolations, and conclusion must be considered part of the text, with the result that in this novel fictional mimesis is always already implicated in hermeneutic problems. Put differently, since Mary was issued by its author, it speaks to us in a historical present that reifies its truths as timeless. But since The Wrongs of Woman is an edited text, it speaks to us from the past and allows us to see how both Wollstonecraft's imitation of reality and the strategies she uses to make us reconstitute that imitation are historically produced and therefore subject to further interpretation. Taken without Godwin's additions, the second novel is already different from the first in making the process of signification hermeneutic rather than directly referential. Though the plot of the novel moves ineluctably toward a catastrophe, the thematization of reading and the polemical link with $A$ Vindication encourage a divinatory reading that will liberate the true significance of the text from the prison of things as they are. Godwin's additions further complicate the text by bringing out its historical and heuristic tendencies. For in surrounding the novel with reminders of his wife's death, Godwin takes the future she has inscribed in the present and places it, too, in the past. His mediation creates a space in which we become aware of the historical forces behind a divinatory 
reading: the post-Enlightenment, even postrevolutionary optimism that allows Wollstonecraft to invest her hopes in the future, and the historically feminine tendency to defer the realization of her project to a reader, even as Maria reposes her hopes in her child and Mary trusts in God. In placing the text within history, Godwin encourages us to read beyond the simplicity of a divinatory reading while also conserving something of that reading. For a posthumous collection has a phenomenological structure similar to that of an epitaph. Because it commemorates and monumentalizes its subject, it asks us to sympathize with her goals. But the very fact of a tombstone, of an inscription, makes personality into something that must be read and situated, so that the epitaphic mode encrypts as well as enshrines.

We must be clear about what it is that Godwin, as his wife's editor and first explicit reader, does not do. His treatment of Wollstonecraft is sympathetic and respectful. But he does not grant her the privilege of prosopopeia or prophecy, and thus enlist the reader into a visionary company. Mary Wollstonecraft is presented not as an unacknowledged legislator like the visionary in Alastor, but as someone whose work was unavoidably incomplete, perhaps in substantive as well as formal ways. Godwin's additions consist only of a brief preface, an 'advertisement' placed between chapters 14 and 15 that outlines the projected plan of the whole, and a conclusion explaining the state of the fragmentary endings. Although these additions do not direct our interpretation, they place a frame around the text and locate us outside it. They create a historical space between author and editor, editor and reader, which becomes constitutive in our experience of the text. Across this space both Godwin's preface and Wollstonecraft's own preface remind us of the author's political project, and the epitaphic mode of a posthumous collection elicits our cooperation in taking it further. A divinatory reading forms part, but not all, of this cooperation. For Godwin's additions implicitly suggest two models of reading that we are likely to intertwine. In the editorial bridge between chapters 14 and 15 , he provides an outline of Wollstonecraft's plan to write the novel in three parts, suggests that the "broken paragraphs and half finished sentences" are "sketches" on the verge of receiving the "finishing touches of her genius," and asks us to complete the text through a traditional hermeneutic ( $M W W$, p. 186). But in the conclusion he insists on the ephexis, the undecisiveness, of philological accuracy and lays before the reader every last fragment of the projected endings. He thus elicits from us a nonrecuperative reading that culturally situates the anxieties and desires that produce various attempts at closure and that outlines these attempts against their silences. Such reading is akin to what Terry Eagleton describes as criticism: "Criticism is not a passage from text to reader: its task is not to 
redouble the text's self-understanding ... [but] to show the text as it cannot know itself, to manifest those conditions of its making (inscribed in its very letter) about which it is necessarily silent." 20

From the interchange between divinatory and critical readings arises a process best decribed as dialectically combining historical and heuristic reading. On the one hand, in divining the work Wollstonecraft intended, we also recognize the psychological and cultural conditions underlying that work and grasp it critically as a conflictual site. In that respect our reading is historical. On the other hand, we are still concerned with the project of the work or with our heuristic continuations of that project. To continue the past into the present, to allow the text a transhistorical function instead of limiting it to the moment of its production, is to conserve at least part of the impulse behind divinatory reading. For a Marxist 'criticism' assumes that the text's meaning is fixed once and for all by the original circumstances of its production, ${ }^{21}$ and this meaning can be recontextualized only through a hierarchical separation between the culture-bound text and its more enlightened modern reader. But the kind of reading proposed here questions this identification of the text with its moment of production and recognizes both that the effects of the text cannot be reduced to its origins and that these effects, in a complex way, are part of an 'intention' evident at least in this text's refusal of closure. Macherey's criticism of Umberto Eco's idea of an 'open' text will help to clarify where an approach oriented toward the reader diverges from a (post)structural Marxism. "If the book does not produce or contain the principle of its own closure," he argues "it is nevertheless definitively enclosed within its own limits. . . The work is finite because it is incomplete." 22 To recognize that the gaps in a text open it to the participation of a future reader is to see the text as both contained within and transcending its historical moment.

\section{Caleb Williams: Metafiction and the Hermeneutics of Suspicion}

It is partly because Wollstonecraft herself did not superintend the publication of the manuscript that we can, to borrow Macherey's important distinction, read The Wrongs of Woman as "produced under determinate conditions" rather than "created by an intention," 23 and hence as

${ }^{20}$ Criticism and Ideology, p. 43 .

${ }^{21}$ I am indebted for this point to my former student Anne Todkill in her unpublished dissertation, "The Historicity of the Text: Recent Theories in Marxist and Rezeptionsästhetik Literary Criticism" (Queen's University, 1985).

${ }^{22}$ Pierre Macherey, A Theory of Literary Production, trans. Geoffrey Wall (London: Routledge and Kegan Paul, 1978), p. 80.

${ }^{23}$ Ibid., p. 78. 
available for historical reading. The circumstances of the novel's publication of course simply foreground a feature of all texts: namely, that they are the property of their readers as well as their authors. Nevertheless, there are writings in which the status of the text as production is something that emerges in the process of its transmission, and ones that deliberately question a substantialist ontology of the text. The Wrongs of Woman falls into the first category. Godwin's Caleb Williams, by contrast, is a work of political metafiction that explicitly raises the question of the relationship between writing, reading, and political action.

To begin with, Williams is employed as Falkland's secretary and librarian, with the task of reading books on Falkland's behalf and preparing "an analytical survey of the plans of different authors, and conjectural speculations upon hints they afforded, tending either to the detection of their errors or the carrying forward their discoveries" $(C W$, p. 6). Moreover, in the later part of the novel he is himself the subject of tales and misrepresentation, and his memoir (Godwin's novel) is therefore addressed to a future reader who must similarly detect error and forward discovery. It is not until Godwin revised the ending, however, that the novel became truly metafictional, making the final courtroom confrontation into a scene of reading rather than a battle of wills, and retrospectively making reading the object of the novel's scrutiny as well as the mode of its operation. The original novel relies on an almost crude hermeneutics of reversal to convert things as they are into things as they should be. It raises reading to a certain level of thematic prominence in the book because the reader is the means by which the vindication of Caleb is to be effected. But Godwin, as is well known, conceived his novel backward, beginning with the third section and the original ending, and ending with the first section. The middle and opening sections are concerned with the "analysis of the private and internal operations of the mind" and employ a "metaphysical dissecting knife in tracing and laying bare the involutions of motive" ( $C W$, p. 339). As Godwin wrote, the opposition between Caleb and Falkland began to collapse, and an ending based on that opposition must have come to seem a repression of the novel's moral complexities. For if Falkland and Caleb are not simply antagonists but also doubles, the fact that the novel is a first-person narrative by Caleb can no longer hinder us from applying to his text whatever methods of reading he applies to Falkland's representation of himself. The revised ending takes account of the disturbing kinship beween the Promethean Caleb and his Jovian opponent and makes this kinship the dialectical ground of a reconciliation, which comes too late for the characters in the story but not too late to have an impact on the reader. The greatest difference between the endings is that the first version concludes not with Caleb's mistrial but with his 
return to prison, and therefore with the figure of imprisonment which is simply the rhetorical reverse of a simplistic and utopian desire for liberation. The new version ends with a much more complex court scene, in which the legal trial becomes entwined with Caleb's confession, with a trial of the inner self. And in substituting trial for imprisonment as the novel's final hermeneutic figure, Godwin turns the novel back on itself, placing not only Falkland and Caleb but also his own ending on trial.

The original novel is a pessimistic inversion of Political Justice, which shows the triumph of evils the Jacobins were fond of indicting: the potential for tyranny unleashed in Tyrrel and even the once noble Falkland by their rank and wealth, the corruption of the law, the greater goodness of outlaws like Gines, and the injustice of the prison system. But from the beginning Caleb's memoir is put forward not simply as a description of things as they are but as an address to future readers with the "faint idea that posterity may by their means be induced to render me a justice which my contemporaries refuse" ( $C W$, p. 3$)$. The terminus of the novel is therefore not in Caleb's imprisonment and madness, but in its effect on us. One can of course say this of most satire, and it is simply that the role of the reader gains greater prominence in Caleb Williams because of the way reading emerges as a motif in the text. From the beginning it is presented as that which brings the truth to light. The first section consists largely of Collins's narrative, which purports to explain the gothic melancholy of Falkland. It tells of the excesses and mysterious death of Tyrrel and attributes Falkland's tempestuous gloom not to the possibility that he is guilty of the murder and the hanging of the Hawkinses, but to his fine if extreme sense of honor, which causes him to feel that Tyrrel's death has cheated him of the chance to avenge publicly his humiliation by the latter. Collins's acquittal of Falkland accords with what we know of Falkland's character, and his story at first has what Caleb claims for his own narrative: "that consistency, which is seldom attendant but on truth" $(C W$, p. 3$)$. But once we proceed to the second section, Collins's narrative, along with the letter from Hawkins and the secret contents of the trunk, become texts to be read for their lacunae and hidden depths $(C W$, p. 101). Through Caleb as reader, Godwin inscribes a model of reading as the unearthing of truth and the correction of past misrepresentations. In finally becoming to Caleb what Caleb has been to Hawkins, we recover a truth of a different kind: the truth of what should rather than of what really did happen. Like The Wrongs of Woman, the original version ends with a trial scene, and it is the blatant unfairness of the judge's decision in favor of Falkland that causes us to replay the scene correctly in the theater of our minds. For the pervasiveness of theatrical metaphors in this text (pp. 90, 3, 79) has made it clear that Caleb's trials and persecution are predetermined by a 
social script, while Caleb himself has introduced the metaphor of his text as evidence to be laid before a court of readers rather than judges $(C W$, p. 106).

Added to the rhetorical effect of Caleb's mistrial and imprisonment is the pathos of his subsequent madness, which makes him into something of a martyr and gives to his testimony a kerygmatic and more than ordinary dimension. The figure of madness serves as a form of mystification, finally disengaging Godwin's ideology from any articulation within the order of social representation and allowing it to address us from the inner sanctum of feeling. The metaphors of testimony and trial have been analyzed by Paul Ricoeur, who suggests that they are analogous, respectively, to revelation and hermeneutics in interpretation. ${ }^{24}$ In the situation of a trial the inner truth of testimony is subjected to a reading that may treat voice as text, analyzing rather than being persuaded by it. One could argue that the coupling of testimony and trial deconstructs the priority of a revelation that precedes its interpretation and discloses truth as a moving army of figures. But it is not until he rewrites the ending and removes the suggestion of martyrdom that Godwin will make the trial into a genuine scene of reading and deny ideology the status of a secular scripture. In the present context, where 'trial' has eschatological as well as judicial connotations, interpretation is perceived as a mistrial to be rectified by a future reader. The submission of inward testimony to the court of current public opinion recognizes the contingencies of the historical process but also condemns this process as a betrayal.

In a curious way the original version, despite its bleak ending, supports Godwin's dictum that sound reasoning and truth, when adequately communicated, must always be victorious over error. ${ }^{25}$ But the revolution effected remains abstract because it depends entirely on a future reader. Godwin's revision of the ending seems intended to make things as they should be into an evolution from and not simply a refutation of things as they are. In the new ending Caleb, instead of being defeated and going mad, comes prepared to accuse Falkland only to find him most "dreadfully reduced" $(C W$, p. 319$)$. He is moved not only to pity but to a scrutiny of the selfish motives that have impelled him to destroy Falkland to save himself. His long speech is therefore an indictment not only of Falkland but also of himself, for having been insensitive to Falkland's virtues. Though suspicious at first that Caleb is using "a pretence of liberality and sentiment, to give new edge to [his] hostility" (CW, p. 324), Falkland is finally so moved that he confesses and in his turn

${ }^{24}$ Essays in Biblical Interpretation, ed. Lewis S. Mudge (Philadelphia: Fortress Press, 1980), pp. $123-53$.

${ }^{25}$ Godwin, Enquiry Concerning Political Justice and Its Influence on Morals, and Happiness, ed. F. E. L. Priestley, 3 vols. (Toronto: University of Toronto Press, 1945), I, 85-92. 
lavishes praise on Caleb. The death of Falkland shortly thereafter and the condemnation of Caleb to a life of remorse make a happy ending impossible. But the project of reconciliation is offered to the reader as one that we can continue. The new ending appears to serve the purposes of political justice far more effectively than the old one, being more dialectical and less rhetorical. For one thing, the reader of the original version might have been uneasy at being used to vindicate Caleb's character, given that Caleb's voyeuristic curiosity makes him the mirror image of Falkland: equally compulsive, and desirous of a power that is simply more passive and secretive than the power exerted by Falkland. By moving beyond the black-and-white claims of the original ending, Godwin makes Caleb's self-justification seem less hypocritical but also makes the possibility of reform more real, since Falkland's conversion is spontaneous and since the old order that he represents is admitted to have some good in it. At the same time, he makes the scene of reconciliation at the end no more than a tendency, an intention. He thus passes on to us the task of applying in our own lives an insight that comes too late to help the characters, unlike Holcroft in Hugh Trevor, where the Macchiavellian Wakefield is converted and lives happily ever after with the virtuous Hugh. For in having Falkland die and deferring an effective reconciliation beyond the narrative itself, Godwin creates a temporal separation between the old society and the new. Unlike Holcroft, he avoids the contradiction of creating the new order within a narrative world he has spent several hundred pages castigating and also avoids making perfectibility into perfection by literalizing a conversion that still requires much moral work.

But as we have suggested, it is really much more than just the ending that is changed. In rereading its previous ending and making the cancellation of the moral Godwin first intended into the dialectical ground for the positing of a new tendency, the text has become a work of political metafication, concerned as much with interpretation as with ideology, and recognizing how the process of writing backward has itself become a process of reading. Narrative and reading thus become subjects of the text. There are numerous references in the book to the construction of "narratives" and "tales," from which one gathers that for Caleb, as for a contemporary critic, narrative is associated with a will to closure, with an internal consistency, that gives the appearance of truth and causality $(C W$, pp. 3, 106, 4). But reading is to some extent a deconstruction, and not simply an amplification of narrative. It is worth quoting Caleb's description of what happens when he is no longer listening to Collins's narrative, and instead is considering it as a text:

At first I was satisfied with thus considering every incident in its obvious sense. But the story I had heard was for ever in my thoughts, and I was 
peculiarly interested to comprehend its full import. I turned it a thousand ways, and examined it in every point of view. In the original communication it appeared sufficiently distinct and satisfactory; but, as I brooded over it, it gradually become mysterious. $(C W$, p. 107$)$

In the first version of the novel the model of reading described here is applied only to Collins's narrative, and not to Caleb's own story, which is apparently to be read in its obvious sense. The second version probes the secrets behind Caleb's own self-representation as well. Thus in its concluding textual somersault the novel has Caleb discard his memoir as "a half-told and mangled tale" ( $C W$, p. 323) and suddenly puts in its place another story, the "plain and unadulterated tale" of Caleb's remorse and confession $(C W$, p. 326). By now, however, the reader has learned to suspect the narrative consistency that gives the appearance of truth. After all, when Caleb had first heard Collins's narrative, he had found "a connection and progress in [it], ... which made it altogether unlike the little village incidents I had hitherto known" ( $C W$, p. 106). Yet Collins's tale had been mined for its buried secrets. There is no reason why Caleb's own tale of remorse and conversion should not similarly prove to contain things it has not said.

At first, it seems that we are meant to take at face value Caleb's remorseful outline of things as they might have been. His last speech is in the form of a confession, and to confess is finally to tell 'the truth.' Moreover, Caleb and Falkland have moved beyond the ambiguity of reading and are present to each other, in a situation where the spoken word seems to carry "conviction to every hearer" $(C W$, p. 324). In Cloudesley, a much later novel where the protagonist Danvers has a similar guilty secret but is made to live up to his remorse by his former employee Cloudesley, the conversion of Danvers occurs when Cloudesley gives up writing letters to him and finally confronts him. Godwin relates the spoken word to the dialectical generation of truth: "A letter is a dead and powerless pleader. All that it says is already put down, and the man that answers it pronounces a decision where there is no one near to dispute or remonstrate. A personal conference ... is a very different thing." 26 But already in the case of Collins's narrative, which is persuasive when first heard but full of gaps when reexamined, Godwin has raised the question of speech as a text. Moreover, as Paul Ricoeur has argued in discussing our culture's explanation of the origin of evil, the confession of sin is itself a complex tissue of fiction and truth, a meaningful action that must be considered as a text. ${ }^{27}$ To confess is to invent a

${ }^{26}$ Cloudesley: A Tale, 2 vols. (New York: J. and J. Harper, 1830 ), II, 46.

${ }^{27}$ The Conflict of Interpretations: Essays in Hermeneutics (Evanston, Ill.: Northwestern University Press, 1974), pp. 272-86. 
cause to explain a series of effects that may elude such explanation; it is also to exchange responsibility for power, to admit guilt for the way things are in order to claim the ability to change them. Confession, in other words, is part of an economy, a system of representation and exchange, in which nothing is simply what it is. Because Caleb's confession is made in the context of a trial, it is not simply the way that Falkland and Caleb have hitherto represented themselves that is subject to crossexamination, but also Caleb's current representation of himself that is on trial. Behind this self-representation is an entire ideology: a 'romantic' ideology of truth and love in which opposites are reconciled through the dialectic of experience, and in which evil is simply error. In the last scene Caleb puts on a highly theatrical performance: a performance so effective that it asks us to listen to this ideology, but also so melodramatic that it asks us to listen for its silences. The ideology of Political Justice can perhaps explain how a not indecent person like Falkland is trapped by errors characteristic of his class into perpetrating evil and using power to protect himself. It cannot explain the motiveless malignity of Tyrrel, a thing of darkness whose psychotic temperament precedes his use of power to safeguard himself. Moreover, Godwin's ideology is equally silent about an issue he will explore in St. Leon: that of how an individual conversion like Falkland's is to change social structures that are larger than any individual, without itself being changed by those structures.

What occurs between the first and second versions of Caleb Williams is somewhat like the development traced in the history of hermeneutics itself. Godwin begins with an almost naive model of reading, in which our role is to reverse the grammar or plot of the novel so as to actualize a psychological meaning (the triumph of truth) that is quite clearly present in the text as desire. In the second version he actually acts out a complication of this model which is more genuinely akin to a divinatory hermeneutics: he invites us to reverse the plot of the novel in order to grasp the tendency behind its psychological meaning, the desire for honesty based on reconciliation that underlies Caleb's defensive desire for vindication. But this divinatory reading becomes in turn a narrative that is subject to reading, a way of arranging and simplifying the evidence. It is a curious coincidence that the reader in this novel, Caleb himself, is figured as a spy. In casting the reader in the role of spy, Kierkegaard will later effect an uncanny displacement of divinatory reading, with its hermeneutics of perfectibility, and will make the process of reading potentially endless. For the spy is a kind of diviner, a reader of other people's secrets, but the spy also possesses secrets, personal motivations for reading a certain way. In an early essay P. N. Furbank suggests that Caleb Williams is "a highly dramatised symbolic picture of Godwin himself in the act of writing Political Justice . . . Caleb 
Williams is clearly Godwin himself, Falkland the ancien régime, and the opening of the trunk is the writing of Political Justice." 28 But as a text that allegorizes itself, Godwin's novel does not simply culminate in the triumphant issuing of Political Justice. It inescapably associates ideology with narrative, and thus with the reading of narrative: reading in the double sense of bringing to life and probing what is hidden.

\section{St. Leon: Reading as History}

To apply theory to life without discovering its hidden articulations and fragmentations is perhaps impossible. Indeed, it is these fragmentations that generate new tendencies and thus make reading a vital part of the economy of political fiction. The symbiotic relation between political desire and its deconstruction emerges strongly in Godwin's next novel St. Leon. St. Leon does not explicitly thematize the problem of reading. Instead, it thematizes its own historical status and emphasizes the relativism of any moral it may appear to urge. The shift from textuality to historicity as a mode of hermeneutic self-reflexiveness is significant, because it brings out the life as well as the intentionality of signs. It results in a deconstructive pragmatism that uncovers the secrets harbored within political and social fictions while allowing them a real and not just a hypothetical viability. The later novel deals with a sixteenth-century aristocrat who gambles away his fortune and submits to a virtuous poverty, until through a compact with a mysterious stranger he acquires the philosopher's stone, which confers immense wealth on him, but at the cost of alienating his family and making him an object of suspicion and persecution. The novel is historical in two ways: it is set in the past and its action covers a considerable period of time, thus registering changes in socio-intellectual values. During the first half St. Leon utilizes his secret for purely personal ends. His use of power is feudal and ostentatious. His attitude to his family is hierarchical, not only in that he does not confide his secret in them (which he has sworn not to do), but also because he wants the satisfaction of being their sole support, despite the fact that his wife Marguerite has from the beginning been an equal economic partner. But the death of Marguerite, St. Leon's imprisonment by the Spanish Inquisition, and his miraculous escape from execution mark a turning point in the novel. To escape detection, St. Leon takes the elixir of youth, becomes forty years younger, and begins a new life as Chatillon, the benefactor of postwar Hungary. His power is now used for political and social justice. He does not set himself above those

28“Godwin's Novels," Essays in Criticism 5 (1955): 215-16. 
he is trying to help as a philanthropist motivated by a desire for fame, but tries to be as inconspicuous as possible (St.L., p. 374). Moreover, he realizes that he cannot change things through a magical and authoritarian transfusion of wealth that will allow him to bestow his largesse while keeping power in his own hands. In a striking anticipation of Marx's critique of money as alienated representation, he tries to use economic power in ways that are not external to the structures they seek to alter:

I easily saw that, if I would confer a substantial benefit on this unfortunate nation, I had scarcely any other means for the purpose, than that of reviving among them a spirit of industry. I was aware that, in the strictness of the term, money was not wealth; that it could be neither eaten nor drunk; . . It was my purpose to stimulate and revive the industry of the nation: I was desirous of doing this with the least practicable violence upon the inclinations and freedoms of the inhabitants. (St.L., pp. 372-73)

In this half of the novel one's sympathies increasingly shift to St. Leon. Marguerite's moral purity had seemed a desirable if pastoral luxury. But her patriotic and honest son Charles, who condemns the impostor Chatillon for not allowing Hungary to starve and for thus strengthening the Turkish occupation, seems inflexible. And if we are inclined to admire anyone, it is St. Leon, "an equivocal character, assuming different names, and wandering over the world with different pretences" (St.L. p. 475).

From the opening pages of the novel, systems of perfectibility are linked to the rather dubious practice of alchemy. Predictably, St. Leon's motives in trying to improve his family's lot and later the economy of Hungary are submitted to a merciless scrutiny, and the base materials out of which his gold is compounded are exposed. But the metaphorical equation of alchemy with ambition is not used unequivocally to condemn him. In this respect the novel resembles another work of Godwin. In his Lives of the Necromancers he demythologizes magic and sees it as a historical phenomenon, a discourse in Foucault's sense. Magic is the form taken in superstitious ages by a will-to-power that would now express itself through scientific experiment. The Faustian condemnation of alchemy as unhallowed emerges as a historically situated rhetoric, and magic itself as a set of metaphysical practices generated by resistance to that rhetoric, and therefore participating in its assumptions. ${ }^{29}$ The historical perspective makes Godwin aware of a certain legitimacy in the (nec)romantic impulse that earlier ages could not discern, but also allows him to see it as something that is a product of its ethos and is not simply in advance of its time. The result is neither an orthodox condemnation

${ }^{29}$ Godwin, Lives of the Necromancers (London: Fred Mason, 1834 ). 
of magic nor a romantic and Promethean elevation of it. Rather, Godwin engages in a historical reading of necromancy, in which he sees it as the sign of a more profound impulse, but without falling into an essentialism that abstracts tenor from vehicle, because the form assumed by this deeper impulse is for the moment part of its nature. His reading is best described as historical and heuristic rather than grammatical or divinatory, because it tries to get at what is behind certain cultural practices, while constituting this deeper will as a constantly shifting political unconscious rather than a transcendental signified.

This treatment of necromancy is inconceivable apart from the historical relativism that accompanies the hermeneutic movement. As Godwin in The Lives of the Necromancers uses methods emerging in biblical hermeneutics to reread the practice of magic and draw out its value for the present, so, too, in St. Leon he turns the historical novel into a heuristic form so as to make his readers separate the moral from the tendency. Because the tale is set in the sixteenth century but addressed to a later reader, we are encouraged to think beyond a moral framework that would either condemn St. Leon for choosing power over value or yield fatalistically to the series of calamities that seems the price of Faustian heroism. But we are not really placed in any other framework and so are not encouraged to convert the tendency into the signified by reading the novel typologically as a story of Jacobin radicalism and its persecution. Whatever social experiments St. Leon performs are, after all, placed behind us as the past and not in front of us as the unheralded future. They become the subject of analysis rather than the object of hope. The historical form, in other words, creates a double displacement and forces us to inhabit the gap between a grammatical reading that accepts the dated moral framework of the original tale and a divinatory reading that might appear to unlock its 'true' revolutionary significance but would also create a different set of lies in the process.

This displacement occurs not only because of the historical distance between text and reader, but because of the historical dimension within the text itself. Critics have disagreed radically about what the novel means. According to B. J. Tysdahl, alchemy "is presented . . . as a symbol of those aspects of society which Godwin wants to criticise," and St. Leon is associated with the false Burkean ideals of honor and chivalry earlier identified with Falkland. ${ }^{30}$ According to Gary Kelly, alchemy is associated with a curiosity "which is also the essence of dissent and intellectual progress," and St. Leon's secret practices remind us that by "several important anti-Jacobin propagandists the French Revolution had been attributed to the thought of the Enlightenment working through 
secret societies such as the Freemasons and Illuminati." ${ }^{11}$ But the novel is not summed up either by a mimetic and grammatical reading that assumes there is no more in it than the condemnatory moral it appears to urge on us, or by a divinatory reading that makes a tendency in it into its ultimate meaning. The novel is, as we have suggested, selfhistoricizing. Because he possesses the elixir of youth, St. Leon lives through more than one period and becomes the vehicle of a worldhistorical spirit that evolves and changes and cannot be subjected to a single moral evaluation. The moral that dominates the first half, where personal power causes St. Leon to neglect his common humanity, is unsettled by the revolutionary tendency of the second half, where he begins to use his power for the social good. But as St. Leon puts the beneficial potential of alchemy into practice, the radical tendency of the novel is submitted to an intense scrutiny. St. Leon finds that money does not have an intrinsic value but is part of a system of representation, and that by using political alchemy to increase the supply of precious metals he inevitably produces an inflationary situation (p. 379). When the populace turns on him for his failure to work miracles, he is, moreover, forced to the un-Godwinian recourse of asking for the help of the occupying Turkish government to protect himself and the commodities he is trying to dispense. What St. Leon discovers is that power always participates in an economy, that it is involved in substitutions that make its structure disjunctive. Yet knowledge is indissolubly linked to power, articulated and facilitated by it, as thought is linked to language. The symbiotic relationship of power and knowledge puts this novel at a considerable distance from the optimism of other Jacobin writers. But this is not to say that the second half ends by confirming the cautionary moral of the first half, as the novel's repetitive rhythm might suggest. Instead, because the Hungarian experiment is historically localized, the reader is again invited to think beyond its failure, to imagine further continuations of the novel's project.

The unfolding of the political novel parallels developments that occur over a more extended period in the hermeneutic tradition itself. The political novel becomes 'romantic' at the point where it crosses the threshold between rhetoric and hermeneutics, making the reader more than simply the recipient of a text that is to be read for its moral. By involving the reader in the making of the text, it releases us from the text of things as they are. At the same time, because such novels create a form in which meaning does not have to be embodied in the text, they avoid the contradiction characteristic of Holcroft's novels, where an idealized ending is superimposed on the real world and made to claim mimetic 
authority. But the introduction of the reader is an ambiguous blessing, because the text that relies on reading to produce its meaning is always under the arrest of further interpretation. What follows is not so much an endless abyssing of meaning as a recognition that if reading is to remain a productive activity, it must be historical and critical rather than prophetic. Like Hyperion and Christabel, The Wrongs of Woman is broken off at a crisis, and the effect (whether intentional or not) is to elicit a divinatory completion. But the editorial frame that Godwin adds to the novel allows us to 'situate' the hermeneutics of the broken text. Likewise, Godwin's revision of Caleb Williams makes interpretation the very subject of the novel and thus translates the divinatory reading that it stages into the ground for a further critical reading. The development described here finds a parallel not only in the way Kierkegaard opens up and complicates Hegelian hermeneutics, by making the reader as diviner into the reader as spy, it also finds a parallel in what was happening in biblical hermeneutics, where the imperialism of the Christian eschatology from which Hegel's secular scripture derives was coming into question. In the work of Schleiermacher the rationalization of gaps in scriptural ideology through typological reading had given way to a disintegrationist reading in which these gaps were attributed to the composite authorship of the Bible. In classical philology F. A. Wolf had similarly argued that the Homeric epics were composite pieces made over a long period of time. Though the early philologists neither intended nor developed the theoretical implications of their research, they laid the groundwork for a reading that would no longer consider texts as revelations, and, more importantly, they left the reader free to interpret the text as produced under determinate conditions rather than as created by a transcendental intention. It is unlikely that Marxist criticism of the modern scriptures could have happened without what Lee Patterson calls the "analytic dissolutions of historicism," 32 and it is in this tradition that Godwin places himself when he publishes his wife's novel, figuring himself as editor and philologist as well as scribe and prophetic reader. This tacit displacement of the hermeneutics of perfectibility had been anticipated in Caleb Williams by the demystifying figure of the reader as spy. Finally, in St. Leon, where the figure of action as alchemy parallels that of reading as espionage, Godwin incorporates his earlier insights at the level of the fiction itself. Instead of thematizing the problem of textuality, he develops a genuinely heuristic form, that of the historical novel, which generates a dialectic between ideology and its reproduction that makes it possible to act within history as well as read through it.

32"The Logic of Textual Criticism," in Jerome J. McGann, ed., Textual Criticism and Literary Inter pretation (Chicago: University of Chicago Press, 1985), p. 78. 